\title{
Research on the Influence Mechanism of Platform Corporate Social Responsibility on Customer Extra-Role Behavior
}

\author{
Wenjun Liu, ${ }^{1}$ Chenye Wang, ${ }^{1}$ Lin Ding $\mathbb{D}^{2},{ }^{2}$ and Cuibo Wang ${ }^{1}$ \\ ${ }^{1}$ School of Management, South-central University for Nationalities, Wuhan 430074, China \\ ${ }^{2}$ School of Accounting, Zhongnan University of Economics and Law, Wuhan 430073, China \\ Correspondence should be addressed to Lin Ding; linding@zuel.edu.cn
}

Received 10 September 2021; Revised 17 October 2021; Accepted 20 October 2021; Published 5 November 2021

Academic Editor: Daqing Gong

Copyright (c) 2021 Wenjun Liu et al. This is an open access article distributed under the Creative Commons Attribution License, which permits unrestricted use, distribution, and reproduction in any medium, provided the original work is properly cited.

Platform enterprises, which are growing in both quantity and scale, have been inseparable from modern life. In China, the laws specific to platform enterprises fall behind their ever-changing business model. Hence, it is an urgent requirement that platform enterprises undertake their social responsibilities, which will influence consumer extra-role behaviors besides bringing reputation advantages to the enterprises. Based on the motivation theory and social exchange theory, this paper divides corporate social responsibility (CSR) into business ethical responsibility and public welfare responsibility using the CSR division method proposed by McWilliams and Siegel, puts forward self-moral restraint as the proxy variable for business ethical responsibility and explains the relationship between CSR and customer extra-role behavior. It is found that customer extra-role behavior is positively influenced by platform enterprises' social responsibility. The perception of interest consensus exerts a positive influence on extrarole behavior, so does the perception of service identity. The public welfare responsibility is positively influenced by business ethical responsibility.

\section{Introduction}

Platform enterprises are required to have the sense of social responsibility. Connecting merchants at one end and consumers at the other end, platform enterprises build a typical two-sided market, in which they have an unequal status to the third-party merchants. With the continuously expanded scale of platform enterprises, they are prone to form monopoly and acquire monopoly premium once controlling an industry. Although Antimonopoly Law has been enacted in China, the law enforcement still lags behind the everchanging business model of platform enterprises. Therefore, corporate social responsibility (CSR) is an urgent requirement for platform enterprises.

By undertaking social responsibilities, platform enterprises can gain long-term values, which are usually manifested by customer extra-role behavior to the advantage of enterprises. Many studies [1, 2] show that consumers' perception of CSR will affect customer extra-role behavior. Fan and Kong [3] mainly explained the mechanism of CSR influence on customer extra-role behavior from the perspective of exchange and motivation. Few researches have explored the content of CSR and carefully studied the influence of different types of CSR on customer extra-role behavior.

With the rapid development of China's digital economy, numerous enterprises and the Internet continue to deeply integrate and grow into platform enterprises. Platform enterprises, which connect merchants at one end and consumers at the other end, construct a typical two-sided market. Evans [4] divided platform enterprises into three types: market-makers, audience-makers, and demand-coordinators. Platform enterprises simultaneously provide services for corporate customers (B-end) and consumers (Cend). Corporate customers (B-end) display commodities via platforms, being able to contact more consumers (C-end). Consumers (C-end) can pick more communities with super quality and competitive price via platforms. The two-sided market is composed of platform enterprises, corporate customers (B-end), and consumers (C-end). The platform 
economy has its own operation laws. The cross-subsidy feature allows the platform to charge more from the corporate customers (B-end) to subsidize the consumers (Cend). It is normal for consumers to use it for free, but it also brings new problems. When the expenses paid by the corporate customers (B-end) are not enough to support all the operating expenses of the platform, or the platform wants to improve its profitability, it hopes to obtain indirect benefits of the consumers (C-end). Therefore, free services are usually accompanied by more and more platform business activities, such as forced to watch ads and the right of free choice is damaged. Traditional researches on customer extra-role behavior seldom consider the business ethics of products, while platform services in digital economy need more attention.

The most classical definition of CSR given in the existing studies derives from the pyramid model proposed by Carroll [5]. In this model, CSR is divided into four dimensions: economic responsibility, legal responsibility, ethical responsibility, and philanthropic responsibility. However, scholars have only concerned the influences of ethical responsibility and philanthropic responsibility on consumers in the existing empirical studies because economic responsibility and legal responsibility are the responsibility and obligation that must be fulfilled by enterprises. McWilliams and Siegel [6] demarcated CSR at a level beyond economic interest and legal restraint, namely, enterprises were proactively dedicated to the behaviors beneficial for social public interests. Under this definition, it is the social responsibility performed by enterprises at the levels of business ethics and public welfare that is the CSR in real sense, which is rightly the CSR definition understood and used in this study.

In this study, multiple consumers from different industries were interviewed. It was discovered that consumers could not precisely know the business ethics level inside platform enterprises, but they could simply judge it by perceiving whether the platform enterprises cared about consumer rights and interests in business operation and whether they were morally restricted by themselves in face of any legal loophole. Hence, consumers' perception of selfmoral restraint of platform enterprises was taken as the proxy variable for business ethical responsibility.

Combined with the characteristics of platform economy, this study divides CSR into two parts: business ethical responsibility and public welfare responsibility and discusses the influence mechanism of these two types of CSR on customer extra-role behavior from the perspective of exchange and motivation.

\section{Theoretical Basis}

2.1. Theory of Customer Extra-Role Behavior. Related researches on customer extra-role behavior originally came from the theory of employee extra-role behavior. After that, Keh and Teo [7] applied this theory to the role of the customer in service activities and proposed the extra-role behavior of the customer, which was considered to be the spontaneous behavior of the customer, usually manifested as cooperation or sharing service experience with other customers. Extra-role behaviors, which take place during or after the service process, will generally generate positive influences on enterprises so that enterprises gain the exclusive competitive edges from customers, thus improving the performance of service enterprises. Customer extra-role behaviors mainly come from customers' emotions and attitudes towards enterprises, which, in turn, derive from customers' cognition of enterprises, such as organizational support, service fairness, and CSR. Groth [8] believed that customer extra-role behavior is a spontaneous behavior similar to citizenship behavior. Ahearne et al. [9] believed that customer extra-role behavior reflects that customer will show more beneficial behavior to the organization rather than only benefit their own interests.

Bartikowski and Walsh [10] divided customer extra-role behaviors into customer-to-enterprise help and customerto-customer help. Groth [8] classified customer extra-role behaviors into help to other customers, referral, and feedback providing. Therefore, customer-to-enterprise help was divided into customer help and customer referral in this study, specifically including: good suggestions from customers to enterprises, problem mining, word-of-mouth, and referral. The customer-to-customer help was done by enterprises, not needing customers to do anything. Besides, this part was related to specific management scenarios, and the research samples of customer-to-customer help could not be certainly found. Therefore, the customer extra-role behaviors in this study only included the part of customerto-enterprise help.

The behavior of platform undertaking corporate social responsibility will make people have positive thoughts and emotions. This positive attitude will make consumers more friendly to the platform and produce positive behaviors such as recommendation and participation in cooperation, thus promoting the establishment of customer extra-role behavior. Huang and Chen [11] pointed out that a good corporate image of social responsibility is conducive to the formation of positive word-of-mouth and can also enable enterprises to obtain long-term relationship benefits, including customer loyalty and customer recommendation behavior in customer extra-role behavior. And customer recommendation behavior is one of the behaviors outside the role of customer. Xiao and Li [12] proposed that corporate social responsibility can positively affect consumers' attitude towards the organization and its products or services. This identity eventually leads to customer extra-role behavior. None of the aforementioned studies included internal management ethics when discussing corporate social responsibility. To sum up, this study puts forward the following hypothesis:

H1a: The perception of platform public welfare responsibility has a positive impact on customer extrarole behavior.

2.2. Corporate Social Responsibility. In the 1920s, Oliver Sheldon, an American scholar, first put forward corporate social responsibility. Carroll [5] put forward the pyramid 
model of corporate social responsibility, which includes four levels: economic responsibility, legal responsibility, ethical responsibility, and philanthropic responsibility. Jin [13] put forward five dimensions of corporate social responsibility based on Chinese cultural environment: "Give back to the society through charity activities," "participate in social public welfare undertakings through sponsoring community and educational and cultural activities," "actively participate in environmental governance and protection," "protect the rights and interests of consumers," and "fulfill economic responsibilities." He believed that if enterprises use part of their profits to give back to the society, actively participates in social public welfare undertakings, and has the courage to assume economic responsibility, it will be easier for them to gain the trust and recognition of consumers.

The aforementioned research shows that there are many forms of the division of the dimensions of corporate social responsibility. Traditional research rarely considers the moral ethics of the product itself, while the platform services in the digital economy needs to focus on the business ethics of the service itself. This study divides CSR into two parts: business ethical responsibility and public welfare responsibility. The essence is to separate the business management ethics from the ethical responsibility of the corporate social responsibility proposed by Carroll as the CSR related to customers. It can also be regarded as separating business management ethics from "protecting consumers' rights" (one of the five dimensions of corporate social responsibility in China) proposed by Jin as CSR related to customers.

Corporate social responsibility is a signal to consumers, that is, there are overlapping interests between enterprises and consumers. If consumers identify with the corporate feedback to the society, they are more likely to identify themselves as members of the enterprise, and they can also benefit indirectly. They think that the corporate feedback to the society is consistent with their own profits [14]. Therefore, this study puts forward the following hypothesis:

H1b: The perception of platform public welfare responsibility has a positive impact on the perception of interest consensus.

$\mathrm{Li}$ and Zhang [15] found that there is a positive correlation between corporate social responsibility and consumer perceived value, and consumer perceived value is conducive to the sales of products and services. Sheth's consumer value theory points out that the value orientation that affects consumer behavior includes two aspects: functional value and social value. Function value is the entity value of the commodity itself, which is usually related to product performance, appearance, durability, and price; social value refers to the public value of consumers' needs, which is the embodiment of consumers' social interests [16].

For specific products, there are overlapping interests between functional value and social value, such as the consumers' demand for business ethics and environmental protection. On one hand, the satisfaction of this demand is the personal satisfaction of the product function. On the other hand, it also adds consumers' demands for public values such as social justice and environmental protection
[17]. Butcher et al. [18] believed that when consumers are unable to obtain relevant information about products and services, they will choose the performance level of CSR as the basis for evaluating the quality of products and services. CSR in the aforementioned research obviously refers to public welfare responsibility, excluding the moral ethics in enterprise products or services. Based on this, this paper puts forward the following hypothesis:

H1c: The perception of platform public welfare responsibility has a positive impact on the perception of service identity.

2.3. Social Exchange Theory. Social exchange theory analyzes social communication through two factors: reward and cost. Although people in a particular relationship do not particularly calculate the reward and cost of a single event, they are concerned about the overall effect of the relationship. Generally speaking, this kind of relationship will make you get more (the reward is more than cost) or lose more (the cost is more than reward). Usually, the most satisfactory social relations are fair ones. People do not like to be exploited by others, but they do not want to take advantage of others.

Social exchange theory embodies the principle of reciprocity, which holds that an individual will show a certain reward behavior after getting the value given by another individual. In the field of service marketing, consumers will show a series of behaviors to the platform based on the concept of reciprocity after obtaining and benefiting from the value provided by the platform. These behaviors are providing suggestions, recommending, participating in cooperation, and other spontaneous consumer out of role behaviors. The service of the platform is recognized by consumers, and consumers will express their support and recognition to the platform. Therefore, this study puts forward the following hypothesis:

H2: Service identity positively affects customer extrarole behavior.

2.4. Motivation Theory. Motivation theory is based on the relationship between individuals and organization. It holds that the behavior of individual to organization is mainly driven by egoism and altruism. The motivation of egoism is the expectation of return and the benefits of the past. Altruism is motivated by the real expectation of individuals to improve the overall interests of the organization. Gruen [19] once said: although customers' suggestions to enterprises will not benefit directly, customers may indirectly benefit from the development of the enterprise or the improvement of service. It also reflects that the interests of customers and enterprises are consistent.

From the perspective of motivation, if consumers want the platform to provide high-quality services or maximize their own welfare, they will show some positive behaviors to the platform, so that the platform can also get more benefits. Therefore, the interests of the platform and consumers are consistent, and this will encourage consumers to make 
recommendations, publicity, and other behaviors. This study makes the following hypothesis:

H3a: The perception of consensus of interests has a positive impact on customer extra-role behavior.

Zhang et al. [20] pointed out in the experimental research based on the perspective of customer interest level: when customers perceive that some aspects of their personal identity coincide with the enterprise values, they will have a sense of identity. The stronger the sense of identity, the easier it is to maintain close psychological connection with the brand. On the contrary, it will reduce the sense of trust and sense of belonging and even produce brand rejection. The recognition of customers due to the sense of belonging will positively affect customers' cognition of other aspects of the enterprise and cover up the shortcomings of the enterprise to a certain extent. It also reflects that consumers' perception of platform interest congruence will affect their perception of service quality, reduce the negative impact of hidden risks on consumers' positive attitude, and then enhance their perception of service identity. This study makes the following hypothesis:

H3b: The perception of consensus of interests has a positive impact on service identity.

2.5. Business Ethics. In the previous traditional transactions, there were few ethical problems in enterprise services or products. However, there are many moral judgments in the platform service under the digital economy: when platform enterprises make profits through various operation rules, do they consider the interests of consumers, or balance in many ways to restrain their business desire? In this study, "selfmoral restraint" is used to express customers' evaluation of business ethics of platform.

Self-discipline of business ethics will have a positive impact on corporate image and credibility and enhance consumers' recognition of corporate brand reputation. Consumer identity will also positively affect consumer outof-role behavior [21]. In addition, the self-discipline of the platform is in line with the expectations of the society. The public expect that the platform they use can operate with high ethical standards. They are willing to trade and cooperate with the platform that meets the ethical standards and are proud of it. This kind of positive emotion will promote consumers' loyalty and identity to the platform and encourage them to have the behavior of recommendation and suggestion, which is the spontaneous behavior outside the role of consumers.

Business ethics, as an intangible resource, can play an important role in platform operation [22]. If the platform has strict self-discipline, consumers' risk perception of the products and services provided by the platform will be reduced. Consumers are willing to accept the products and services provided by the platform, believing that they will not bring serious adverse effects to themselves. Therefore, consumers' moral cognition of the platform will affect their consumption behavior and service quality perception. If the platform always abides by business ethics, consumers' recognition of products and services will be enhanced. Therefore, this study puts forward the following hypotheses:

H4a: Platform business ethical responsibility has a positive impact on customer extra-role behavior.

H4b: Platform business ethical responsibility has a positive impact on service identity perception.

Yan and Chen [23] believed that the evaluation dimensions of Chinese consumers' e-commerce website marketing moral behavior include the reliability of transaction results, the security of transaction process, the integrity of promotion, the fairness of competition, and the appropriateness of advertising. These dimensions are consistent with the direct interests of consumers. For a platform with good moral restraints, consumers think that the moral behavior of the platform is not only for their own development but also to safeguard the interests of consumers, so it will produce the recognition that the interests of the platform are consistent with their own interests. Based on this, this study puts forward the following hypothesis:

H4c: Platform business ethical responsibility has a positive impact on perception of interest consensus.

The platform has business ethical responsibility, which is conducive to the fulfillment of moral responsibility in social responsibility. Lyu [24] and Wang [25] pointed out in their research that corporate ethics originates from a series of normative contracts, which has an important impact on corporate social responsibility. Consumers identify with the self-discipline of platform enterprises, which means that they identify with the business ethics of platform enterprises. When platform enterprises give back to society, solve social problems, or make charitable donations, consumers will follow the balance theory and combine the two aspects of cognitive object to determine the attitude of the cognitive subject. At this time, consumers have identified with one aspect, so it is easier to make altruistic attribution and identify with the sincerity of platform enterprises to give back to the society. Based on the aforementioned analysis, this paper puts forward the following hypothesis:

H4d: Platform business ethical responsibility has a positive impact on the perception of platform public welfare responsibility.

2.6. Research Model. In summary, the research model is shown in Figure 1.

\section{Research Design}

3.1. Questionnaire Design and Variable Measurement. In this study, the data collection was completed through questionnaire survey. Variables were measured using Likert-type 7-point scale. The measurement methods and contents of most indexes referred to predecessors' studies. Public welfare responsibility was defined by reference to the definition given by Carroll [5] and Jin [13], customer extra-role behaviors demarcated according to the study of Lyu and Wei [26], the perception of interest consensus defined based on 


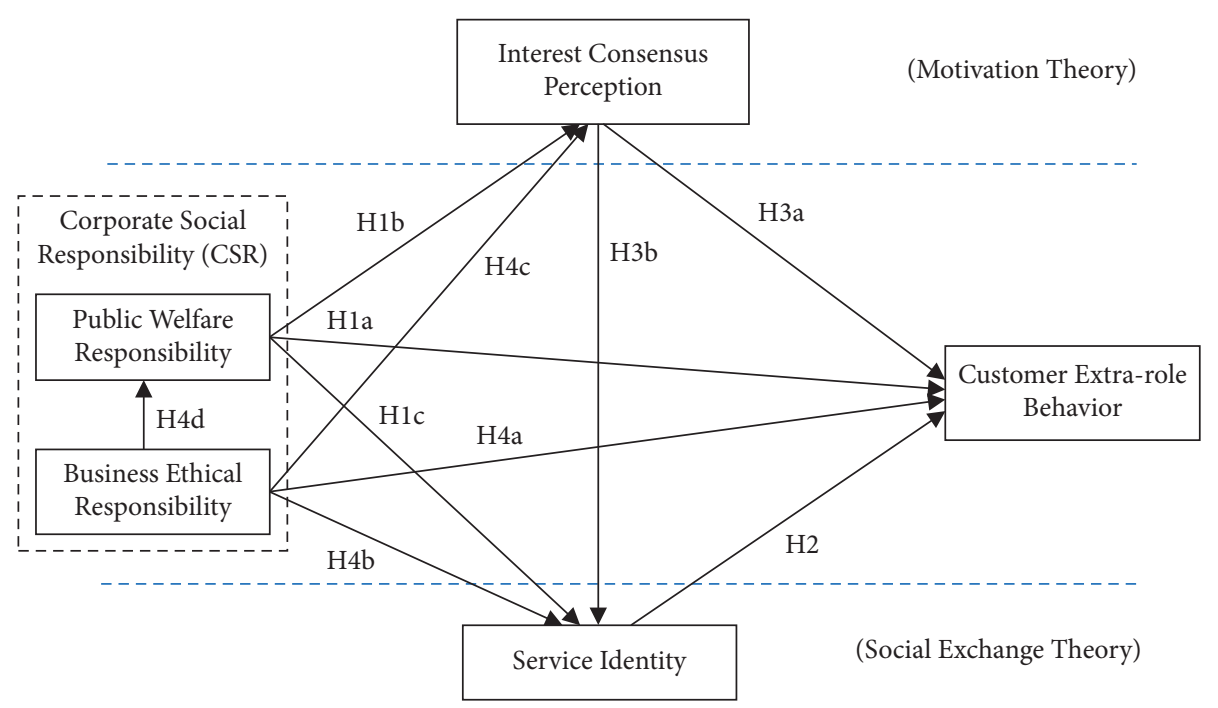

Figure 1: Research model.

the definition given by Xiao and $\mathrm{Li}$ [12], and business ethical responsibility defined by Wang [27]. The service identity was developed according to the definitions, including satisfaction, value, and usefulness. The measurement indexes and sources of the questionnaire are listed in Table 1.

\subsection{Questionnaire Collection and Sample Distribution.} The formal questionnaire is divided into paper file and online questionnaire. The questionnaire of paper file mainly includes customers around the shopping mall and college students.

Online questionnaire through online survey platform: questionnaire network (https://www.wenjuan.com) to collect data. The respondents are mainly college students, junior and senior high school students, and their parents' colleagues.

The survey data were obtained from December 6, 2020, to December 13, 2020. A total of 489 questionnaires were collected, including 276 paper questionnaires and 213 online questionnaires. Remove some invalid questionnaires, 377 valid questionnaires were collected, and the effective rate was $77.1 \%$.

First, the demographic distribution of the questionnaire data was analyzed. See Table 2 for the characteristic distribution. The descriptive statistical results of Likert-type scale for the items in the questionnaire are as seen in Table 3.

3.3. Result Analysis. In this study, the measurement model was tested through exploratory factor analysis and confirmatory factor analysis. Moreover, the reliability, construct validity, convergent validity, and discriminant validity of the scale were tested, too. The followings were done according to the recommendation from Anderson and Gerbing [28]:

(1) The reliability of scale was judged by combining Cronbach's alpha coefficient ( $\alpha$ value) and composite reliability (CR). When both $\alpha$ value and CR were greater than 0.8 , the scale was of good reliability, and the data stability and consistency passed the test.

(2) The construct validity of scale was tested by the load of each index on the corresponding factor in "exploratory factor analysis." When the factor load of each index was greater than 0.6 and much greater than the cross-load on the other factors (namely: the factor structure extracted in the exploratory factor analysis was consistent with the dimension of scale/ index in the initial questionnaire), the scale had favourable construct validity.

(3) The convergent validity of scale was tested through the average variance extracted (AVE) of each factor in the "confirmatory factor analysis." When the AVE of each factor was greater than 0.5 , the scale showed excellent convergent validity.

(4) The discriminant validity of scale was judged by differentiating "square root of AVE value of each factor" from "the correlation coefficient of this factor with the other factors" in the "discriminant factor analysis." The scale was proved to have good discriminant validity if the square root of AVE value of each factor was significantly greater than the correlation coefficient of this factor with the other factors.

The measurement model was tested in this study according to the aforementioned recommended steps.

To investigate whether the sample data were suitable for the factor analyses, KMO and Bartlett's degree of sphericity test should be done first. In this study, the KMO value was calculated via SPSS software as 0.942 , which was greater than the minimum required fitted value, 0.6, and Bartlett's degree of sphericity test result was significant at a level of 0.01 , indicating that the data were suitable for the factor analyses.

During the factor analyses, a total of 5 factors were extracted, and about $82.349 \%$ of variance was explained, specifically as seen in Table 4 . The factor structure extracted 
TABLE 1: Research scale.

\begin{tabular}{|c|c|c|}
\hline Variable/reference & Number & Item \\
\hline Public welfare responsibility (Jin [13]; Carroll [5]) & $\begin{array}{l}\text { PWR 1 } \\
\text { PWR } 2 \\
\text { PWR } 3 \\
\text { PWR } 4 \\
\text { PWR } 5\end{array}$ & $\begin{array}{l}\text { The platform is an enterprise concerned with social problems } \\
\text { The platform is actively giving back to the society } \\
\text { The platform is actively participating in solving social problems } \\
\text { The platform is always actively engaged in public welfare } \\
\text { The platform supports environmental protection }\end{array}$ \\
\hline Customer extra-role behavior (Lyu and Wei [26]) & $\begin{array}{l}\text { CEB1 } \\
\text { CEB2 } \\
\text { CEB3 } \\
\text { CEB4 } \\
\text { CEB5 }\end{array}$ & $\begin{array}{l}\text { I am willing to make suggestions on the development of the platform } \\
\text { If someone maliciously accuses the platform, I will defend it } \\
\text { I am willing to provide help to the platform (including other users) } \\
\text { I will promote the advantages of the platform to others } \\
\text { I will actively participate in the activities of the platform }\end{array}$ \\
\hline Service identity definition & $\begin{array}{l}\text { SI1 } \\
\text { SI2 } \\
\text { SI3 }\end{array}$ & $\begin{array}{l}\text { I am very satisfied with the services provided by the platform } \\
\text { I agree with the value of the services provided by the platform } \\
\text { I think the services provided by the platform are very useful }\end{array}$ \\
\hline Interest consensus perception Xiao and Li [12] & $\begin{array}{l}\text { ICP1 } \\
\text { ICP2 } \\
\text { ICP3 } \\
\text { ICP4 }\end{array}$ & $\begin{array}{l}\text { While the platform gains benefits, I can also get benefits } \\
\text { The better the platform develops, the more benefits I get } \\
\text { I have the same interests as the platform } \\
\text { The interests of the platform are related to my own interests }\end{array}$ \\
\hline Business ethical responsibility Wang [27] & $\begin{array}{l}\text { BER1 } \\
\text { BER2 } \\
\text { BER3 } \\
\text { BER4 } \\
\text { BER5 }\end{array}$ & $\begin{array}{c}\text { The platform does almost nothing immoral } \\
\text { The platform has a good standard of moral behavior } \\
\text { The platform has good self-discipline } \\
\text { The platform will not deliberately do anything against morality } \\
\text { I think the platform is morally self-disciplined }\end{array}$ \\
\hline
\end{tabular}

TABLE 2: Sample distribution characteristics.

\begin{tabular}{lccc}
\hline Option & Features & Frequency $(N=377)$ & Proportion $(\%)$ \\
\hline \multirow{2}{*}{ Gender } & Male & 180 & 47.7 \\
& Female & 197 & 52.3 \\
\hline \multirow{3}{*}{ Education } & Senior high school and below & 70 & 18.6 \\
& Junior college & 86 & 22.8 \\
& Undergraduate course & 108 & 28.6 \\
& Master degree or above & 113 & 30 \\
Age & Under 18 & 40 & 10.6 \\
& $18-25$ years old & 85 & 22.6 \\
& $26-35$ years old & 91 & 24.1 \\
& $36-45$ years old & 89 & 23.6 \\
Occupation & Above 46 & 72 & 19.1 \\
& Student & 93 & 24.7 \\
& Company/enterprise staff & 96 & 25.5 \\
& Civil servants/employees of public institutions & 107 & 28.3 \\
\hline
\end{tabular}

in the exploratory factor analysis had consistent dimensions with the scale/index in the initial questionnaire, manifesting the outstanding construct validity of the scale.

Next, confirmatory factor analysis was performed via AMOS software. The standard loads of all factors passed the test at the significance level of 0.01 , specifically as seen in Table 5. The data in the table showed that both $\alpha$ value and CR were greater than 0.8 , indicating the good reliability of the model scale. The AVE value of each factor was greater than 0.5 , meaning good convergent validity of the model scale.

Confirmatory factor analysis (CFA) was used to study the discriminant validity. When the square root value of
AVE of all factors is much larger than the correlation coefficient between the factor and other factors, it shows that the scale has good discriminant validity.

As can be seen from Table 6, the minimum value of AVE square root is 0.856 , and the maximum value of correlation coefficient between factors is 0.703 . The former is greater than the latter, which means that the data of this study have good discriminant validity. Recommended value and actual value of model fitting index are shown in Table 7 .

Combined with the aforementioned analysis, Amos software is further used to test the hypothesis. The estimated values of the standardized structure of the research model are shown in Table 8. The perception of platform public 
Table 3: Descriptive statistical results.

\begin{tabular}{|c|c|c|c|c|c|c|c|}
\hline Variable & Index & $N$ & Mean & Median & $\mathrm{SD}$ & Min & Max \\
\hline \multirow{5}{*}{ PWR } & PWR1 & 377 & 5.32 & 6.00 & 1.554 & 1 & 7 \\
\hline & PWR2 & 377 & 5.29 & 5.00 & 1.478 & 1 & 7 \\
\hline & PWR3 & 377 & 5.16 & 5.00 & 1.497 & 1 & 7 \\
\hline & PWR4 & 377 & 5.01 & 5.00 & 1.467 & 1 & 7 \\
\hline & PWR5 & 377 & 5.18 & 5.00 & 1.475 & 1 & 7 \\
\hline \multirow{5}{*}{ CEB } & CEB1 & 377 & 5.19 & 5.00 & 1.480 & 1 & 7 \\
\hline & CEB2 & 377 & 4.74 & 5.00 & 1.560 & 1 & 7 \\
\hline & CEB3 & 377 & 5.06 & 5.00 & 1.426 & 1 & 7 \\
\hline & CEB4 & 377 & 5.12 & 5.00 & 1.528 & 1 & 7 \\
\hline & CEB5 & 377 & 4.94 & 5.00 & 1.493 & 1 & 7 \\
\hline \multirow{3}{*}{ SI } & SI1 & 377 & 5.49 & 6.00 & 1.355 & 1 & 7 \\
\hline & SI2 & 377 & 5.60 & 6.00 & 1.280 & 1 & 7 \\
\hline & $\mathrm{SI} 3$ & 377 & 5.66 & 6.00 & 1.293 & 1 & 7 \\
\hline \multirow{4}{*}{ ICP } & ICP1 & 377 & 4.88 & 5.00 & 1.658 & 1 & 7 \\
\hline & ICP2 & 377 & 4.68 & 5.00 & 1.674 & 1 & 7 \\
\hline & ICP3 & 377 & 4.43 & 4.00 & 1.655 & 1 & 7 \\
\hline & ICP4 & 377 & 4.47 & 5.00 & 1.712 & 1 & 7 \\
\hline \multirow{5}{*}{ BER } & BER1 & 377 & 4.83 & 5.00 & 1.579 & 1 & 7 \\
\hline & BER2 & 377 & 4.83 & 5.00 & 1.570 & 1 & 7 \\
\hline & BER3 & 377 & 4.86 & 5.00 & 1.597 & 1 & 7 \\
\hline & BER4 & 377 & 5.12 & 5.00 & 1.520 & 1 & 7 \\
\hline & BER5 & 377 & 5.05 & 5.00 & 1.517 & 1 & 7 \\
\hline
\end{tabular}

TABLE 4: Rotation factor matrix.

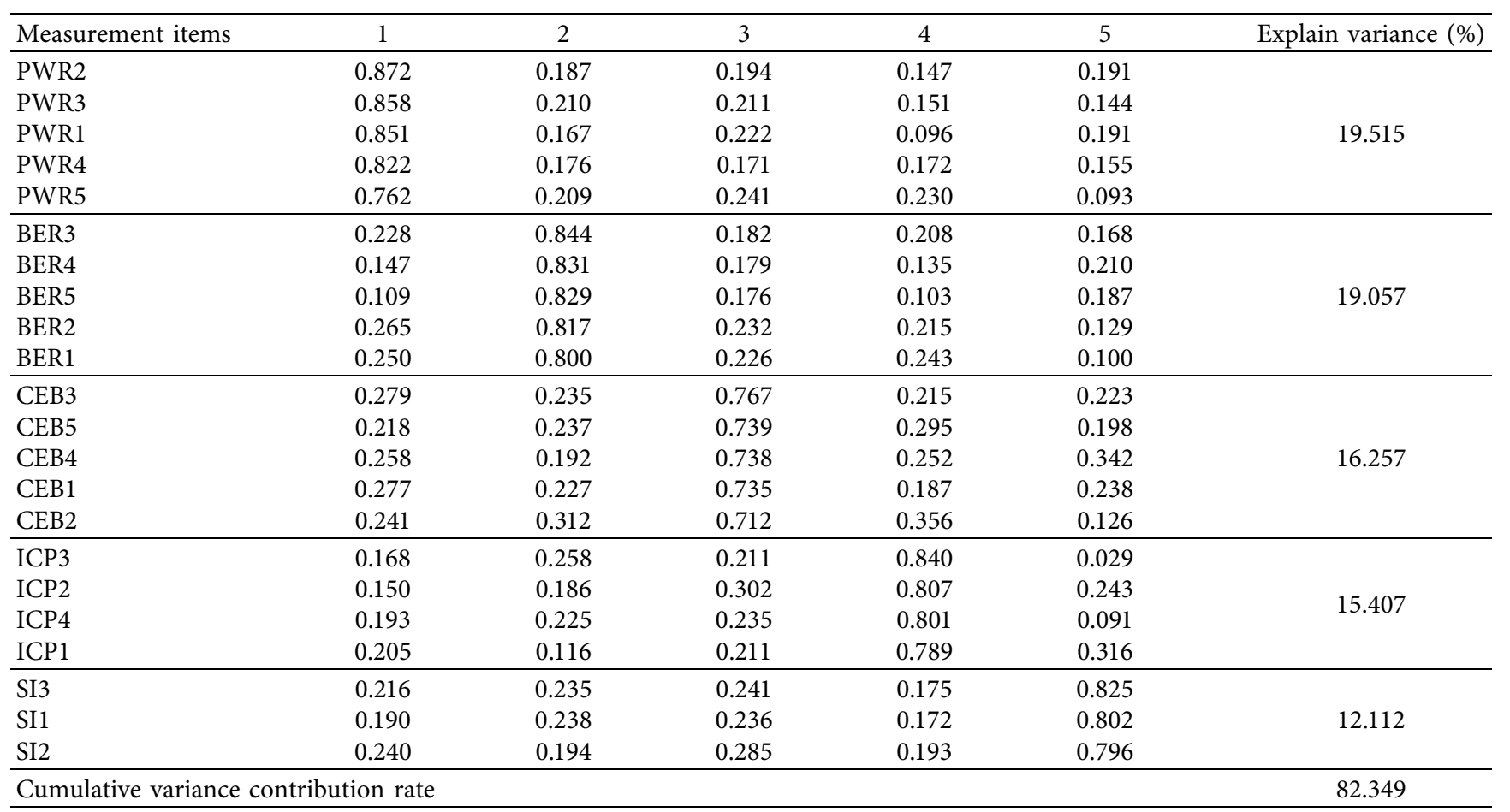

welfare responsibility exerts significant positive influences on customer extra-role behaviors, perception of interest consensus, and service identity. Customer extra-role behaviors are significantly positively influenced by the perception of service identity. The perception of interest consensus shows remarkable positive influences on customer extra-role behaviors and service identity. The perception of platform business ethical responsibility generates positive influences on customer extra-role behaviors, service identity, and perception of interest consensus, and besides, it exerts a positive influence on the perception of platform public welfare responsibility. 
TABLE 5: Reliability and convergent validity analysis.

\begin{tabular}{|c|c|c|c|c|c|}
\hline Factor & Index & Standard load & AVE & CR & $\alpha$ \\
\hline \multirow{5}{*}{ Customer extra-role behavior (CEB) } & CEB1 & 0.82 & \multirow{5}{*}{0.733} & \multirow{5}{*}{0.932} & \multirow{5}{*}{0.932} \\
\hline & CEB2 & 0.86 & & & \\
\hline & CEB3 & 0.87 & & & \\
\hline & CEB4 & 0.89 & & & \\
\hline & CEB5 & 0.84 & & & \\
\hline \multirow{5}{*}{ Public welfare responsibility (PWR) } & PWR1 & 0.91 & \multirow{5}{*}{0.775} & \multirow{5}{*}{0.945} & \multirow{5}{*}{0.946} \\
\hline & PWR2 & 0.95 & & & \\
\hline & PWR3 & 0.93 & & & \\
\hline & PWR4 & 0.82 & & & \\
\hline & PWR5 & 0.78 & & & \\
\hline \multirow{3}{*}{ Service identity (SI) } & SI1 & 0.84 & \multirow{3}{*}{0.781} & \multirow{3}{*}{0.915} & \multirow{3}{*}{0.913} \\
\hline & SI2 & 0.90 & & & \\
\hline & $\mathrm{SI} 3$ & 0.91 & & & \\
\hline \multirow{5}{*}{ Business ethical responsibility (BER) } & BER1 & 0.90 & \multirow{5}{*}{0.77} & \multirow{5}{*}{0.944} & \multirow{5}{*}{0.944} \\
\hline & BER2 & 0.93 & & & \\
\hline & BER3 & 0.92 & & & \\
\hline & BER4 & 0.83 & & & \\
\hline & BER5 & 0.80 & & & \\
\hline \multirow{4}{*}{ Interest consensus perception (ICP) } & ICP1 & 0.87 & \multirow{4}{*}{0.75} & \multirow{4}{*}{0.923} & \multirow{4}{*}{0.923} \\
\hline & ICP2 & 0.92 & & & \\
\hline & ICP3 & 0.85 & & & \\
\hline & ICP4 & 0.82 & & & \\
\hline
\end{tabular}

TABLE 6: Discriminant validity.

\begin{tabular}{|c|c|c|c|c|c|}
\hline & PWR & BER & ICP & CEB & SI \\
\hline PWR & 0.880 & & & & \\
\hline BER & 0.536 & 0.877 & & & \\
\hline $\mathrm{ICP}$ & 0.485 & 0.552 & 0.866 & & \\
\hline CEB & 0.626 & 0.637 & 0.703 & 0.856 & \\
\hline SI & 0.542 & 0.552 & 0.565 & 0.694 & 0.884 \\
\hline
\end{tabular}

TABLE 7: Recommended value and actual value of model fitting index.

\begin{tabular}{|c|c|c|c|c|c|c|}
\hline Fitting index & $\chi^{2} / d f$ & RMSEA & GFI & AGFI & CFI & NFI \\
\hline Recommended value & $<3$ & $<0.08$ & $>0.80$ & $>0.80$ & $>0.90$ & $>0.90$ \\
\hline The value of this study & 2.83 & 0.07 & 0.873 & 0.839 & 0.956 & 0.933 \\
\hline
\end{tabular}

TABLE 8: Standardized structure estimation of research model.

\begin{tabular}{|c|c|c|c|c|}
\hline Hypotheses & Standardized estimate & SE & CR & $P$ value \\
\hline Platform public welfare responsibility $\longrightarrow$ customer extra-role behavior & 0.21 & 0.039 & 4.657 & $* * *$ \\
\hline Service identity $\longrightarrow$ customer extra-role behavior & 0.29 & 0.053 & 5.808 & $* * *$ \\
\hline Interest consensus perception $\longrightarrow$ customer extra-role behavior & 0.34 & 0.041 & 7.026 & $* * *$ \\
\hline Platform business ethical responsibility $\longrightarrow$ customer extra-role behavior & 0.18 & 0.039 & 3.787 & $* * *$ \\
\hline Platform business ethical responsibility $\longrightarrow$ service identity & 0.24 & 0.045 & 4.255 & $* * *$ \\
\hline Platform public welfare responsibility $\longrightarrow$ service identity & 0.26 & 0.044 & 4.888 & $* * *$ \\
\hline Interest consensus perception $\longrightarrow$ service identity & 0.3 & 0.045 & 5.347 & $* * *$ \\
\hline Platform business ethical responsibility $\longrightarrow$ interest consensus perception & 0.41 & 0.055 & 7.290 & $* * *$ \\
\hline Platform public welfare responsibility $\longrightarrow$ interest consensus perception & 0.26 & 0.056 & 4.820 & $* * *$ \\
\hline Platform business ethical responsibility $\longrightarrow$ platform public welfare responsibility & 0.54 & 0.047 & 10.971 & $* * *$ \\
\hline
\end{tabular}


TABLE 9: Hypothesis test results.

\begin{tabular}{|c|c|c|}
\hline & Hypothetical content & Result \\
\hline H1a & Platform public welfare responsibility has a positive impact on customer extra-role behavior & Accept \\
\hline $\mathrm{H} 1 \mathrm{~b}$ & Platform public welfare responsibility has a positive impact on perception of consensus of interests & Accept \\
\hline $\mathrm{H} 1 \mathrm{c}$ & Platform public welfare responsibility has a positive impact on service identity & Accept \\
\hline $\mathrm{H} 2$ & Service identity has a positive impact on customer extra-role behavior & Accept \\
\hline $\mathrm{H} 3 \mathrm{a}$ & Perception of consensus of interests has a positive impact on customer extra-role behavior & Accept \\
\hline $\mathrm{H} 3 \mathrm{~b}$ & Perception of consensus of interests has a positive impact on service identity & Accept \\
\hline $\mathrm{H} 4 \mathrm{a}$ & Platform business ethical responsibility has a positive impact on customer extra-role behavior & Accept \\
\hline $\mathrm{H} 4 \mathrm{~b}$ & Platform business ethical responsibility has a positive impact on service identity & Accept \\
\hline $\mathrm{H} 4 \mathrm{c}$ & Platform business ethical responsibility has a positive impact on perception of consensus of interests & Accept \\
\hline $\mathrm{H} 4 \mathrm{~d}$ & Platform business ethical responsibility has a positive impact on platform public welfare responsibility & Accept \\
\hline
\end{tabular}

\section{Conclusion and Suggestions}

4.1. Research Results and Explanation. Through questionnaire design, data collection, and model construction, 10 validation results were obtained, as shown in Table 9. This paper will explain the following assumptions and then find out the key factors that affect customer extra-role behavior based on the results of data analysis.

This paper studies the influencing factors of customer extra-role behavior from four aspects: public welfare responsibility, business ethical responsibility, interest consensus perception, and service identity.

(1) The hypothesis that the public welfare responsibility of platform has a positive impact on customer extrarole behavior (H1a) is established. The hypothesis that the public welfare responsibility of platform has a positive impact on the perception of consensus of interests (H1b) is established. The hypothesis that the public welfare responsibility of platform has a positive impact on service identity (H1c) is established.

Corporate social responsibility usually refers to a series of activities in which the platform completes its obligations to the social environment, investors, and other stakeholders. The main motivation for platform to undertake social responsibility is that positive social responsibility perception can bring huge potential benefits. When the platform actively fulfills its social responsibility and completes the environmental protection or the performance of stakeholders, consumers will have a positive attitude towards the whole platform and its products or services when they feel the corporate social responsibility. Consumers will perceive the consistent interests of themselves with the platform and eventually produce more customer extra-role behavior.

(2) The hypothesis that service identity has a positive impact on customer extra-role behavior ( $\mathrm{H} 2)$ is established.

Consumers will be satisfied when they think the products or services provided by the platform are valuable or useful. This positive attitude will make consumers form a good impression of the whole platform and even produce a sense of identity. Under the combined effect of these positive attitudes and other factors, consumers will have spontaneous behaviors beyond the role of recommendation, advice, and loyalty.

(3) The hypothesis that perception of consensus of interests has a positive impact on customer extra-role behavior ( $\mathrm{H} 3 \mathrm{a})$ is established. The hypothesis that perception of consensus of interests has a positive impact on service identity (H3b) is established.

When consumers perceive that some aspects of their personal identity coincide with enterprise values, or can benefit at the same time, users will have a sense of identity with the platform. The stronger the sense of identity is, the easier it is to maintain close psychological connection with the brand and promote the emergence of customer extra-role behavior. The consistency between the platform and consumers' self-interest makes consumers believe that the behavior of the platform is not only for profit but also increases consumers' welfare. This makes consumers more supportive of the platform and think that the products or services provided by the platform are more useful and satisfied.

(4) The hypothesis that platform business ethical responsibility has a positive effect on customer extrarole behavior ( $\mathrm{H} 4 \mathrm{a})$ is established. The hypothesis that platform business ethical responsibility has a positive effect on service identity (H4b) is established. The hypothesis that platform business ethical responsibility has a positive effect on the perception of consensus of interests ( $\mathrm{H} 4 \mathrm{c}$ ) is established. The hypothesis that platform business ethical responsibility has a positive impact on platform public welfare responsibility (H4d) is established.

Corporate business ethical responsibility is the forerunner of enterprise's public welfare responsibility, which expresses the consistency between enterprise's behavior and the values expected by the public. Consumers will evaluate the enterprise from the perspective of values and form different emotions about the brand, products, and services. When the platform has strict self-requirements, acts in accordance with the law and does not touch the moral bottom line, consumers can perceive the consistency 
of their own interests and platform interests and then have a positive impact on customer extra-role behavior.

4.2. The Significance of Management. In recent years, corporate social responsibility and corporate ethics have been paid more and more attention, and customer extra-role behavior plays an increasingly important role in the development of enterprises. Considering the background of The Times, digital technologies represented by Big Data, cloud computing, Internet of things, and artificial intelligence are increasingly penetrating into traditional enterprises and Internet platforms. This creates new opportunities for the transformation and upgrading of traditional enterprises and the reform of existing platforms. For platforms, to achieve high-quality development, they need to win more extra-role behaviors of consumers and maintain a longterm, harmonious, and stable relationship with them. For consumers, enterprises actively fulfill their social responsibilities, and strict self-requirements will become an important strategy to win recognition and trust.

4.2.1. The Internet Platform Should Improve Its Moral Requirements to Achieve High-Quality Development in the Digital Economy. Digital economy has become an important driving force of industrial transformation and upgrading and also the commanding height of a new round of global industrial competition. In the era of digital economy, traditional enterprises are transforming to the Internet platform and the sinking of consumer market to expand the growth space of network consumption. In this wave, the platform needs to obtain sustainable and stable development power and nonreplicable competitive advantage, at the same time; it also requires strict self-discipline to achieve high-quality development.

With the development of the market economy, the emergence of unfair competition and monopoly makes the business ethics behavior of platform enterprises show more and more important practical significance. Business ethics is the business practice and code of conduct that the platform should abide by. While creating economic benefits and pursuing profit maximization, the platform should always abide by law, be honest and trustworthy, and protect the interests of consumers. Platform enterprises should perfect their user feedback information system, strengthen the selfdiscipline, and consider their self-morality during the business promotion. Only in this way can it conform to the rational and healthy competitive environment of the market. From the calculation results, it can be seen that consumers are more inclined to the platform with higher moral requirements and will cultivate positive emotions such as loyalty and identification to the platform in the process of transaction cooperation. This will help enterprises gain competitive advantage and improve brand value in fair competition.

In addition to the active constraints of the platform itself, government departments should also strengthen the supervision of the platform operation, improve the relevant laws and regulations, create a healthier development environment for the Internet platform, improve the economic benefits of the platform, and promote the value-added of the overall value to achieve a win-win situation between the platform itself and its stakeholders. Platform enterprises should establish and perfect their property isolation systems and strengthen the review and penalty of illegal behaviors on platforms.

4.2.2. The Platform Should Pay Attention to Customer Extra-Role Behavior. At present, there are more and more antiunfair competition and antimonopoly censorship and supervision on the Internet platform to maintain the market order of fair competition. In this case, the Internet platform should strive for customer extra-role behavior so as to get consumers' recognition, rather than just let consumers have the intention of continuing to use.

From the calculation results, customer extra-role behavior shows consumers' positive emotions in loyalty, identity, and self-realization. On one hand, these behaviors not only create a good image for the enterprise but also give the enterprise the ability to alleviate and resist the crisis. On the other hand, it stimulates the innovation of platform products and services and improves other consumers' perception of platform value. If consumers cannot produce positive spontaneous behavior for the platform, it is very easy for the platform to shift, and it is easier for consumers to lose favour in the international cycle. Therefore, the platform should motivate customer extra-role behaviors by means of enhancing the perception of interest consensus and service identification, find its own advantages and disadvantages through consumers' behavior, to carry out self-motivation and improvement, and finally cultivate a strong sense of global identity on the basis of local consumer identity. When failing to directly gain interests from customers, enterprises can indirectly seek for profits through customer extra-role behaviors, which can help enterprises to improve their products, recommend customers, and save the $R \& \mathrm{D}$ and marketing expenses.

4.2.3. The Platform Needs to Enhance the Awareness of Actively Fulfilling Corporate Social Responsibility. When the existing social norms cannot keep up with the emerging technology behavior, the platform needs to bear certain social responsibility. In recent years, consumers' perception of the platform not only stays in quality of products or services but also the social responsibility of the platform will affect consumers' attitude towards the platform.

This paper concludes that social responsibility has a positive impact on service identity, the perception of consensus of interests, and customer extra-role behavior. A good sense of social responsibility can build a close relationship between the platform and consumers. In addition, the platform actively fulfilling its social responsibility can not only improve its functional value but also enhance its social value. Therefore, platform enterprises should fully realize the role of social responsibility in maintaining the relationship between platform and consumers, take social responsibility 
as an important part of development and reform, and undertake their due obligations, so as to realize the sustainable development of enterprises.

4.3. Research Prospects and Shortcomings. The deficiencies of this paper and the future research focus on the following three aspects: first, the scope of this empirical survey cannot cover all kinds of Internet platforms. Although the applicability of the index system on several types of platforms has been preliminarily verified, it is still necessary to introduce to more platforms for more extensive reliability, validity evaluation, and universal applicability tests. Second, other influencing factors of consumers' out of role behavior need to be further demonstrated, such as individual factors of customers, short-term transactions, or relationship maintenance between customers and platforms. Third, there are great differences in consumer behavior between Eastern and Western consumers in different cultural backgrounds. Therefore, it is of academic significance to conduct crosscultural research on the extra-role behavior of Eastern and Western consumers.

\section{Data Availability}

The data used to support the findings of this study are available from the corresponding author upon request.

\section{Conflicts of Interest}

The authors declare that they have no conflicts of interest.

\section{Acknowledgments}

This paper was supported by the Key Teaching and Research Foundation of South-Central University for Nationalities (grant no: JYZD19031).

\section{References}

[1] W.-M. Hur, T.-W. Moon, and H. Kim, "When does customer CSR perception lead to customer extra-role behaviors? The roles of customer spirituality and emotional brand attachment," Journal of Brand Management, vol. 27, no. 4, pp. 421-437, 2020.

[2] M. Soni, S. Dawar, and A. Soni, "Probing consumer awareness \& barriers towards consumer social responsibility: a novel sustainable development approach," International Journal of Sustainable Development and Planning, vol. 16, no. 1, pp. 89-96, 2021.

[3] J. Fan and J. W. Kong, "Research on foreign customer citizenship behavior," Foreign economy and management, vol. 31, no. 9, pp. 47-52, 2009.

[4] D. S. Evans, "Some empirical aspects of multi-sided platform industries," Review of Network Economics, vol. 2, no. 3, pp. 191-209, 2003.

[5] A. B. Carroll, "The pyramid of corporate social responsibility: toward the moral management of organizational stakeholders," Business Horizons, vol. 34, no. 4, pp. 39-48, 1991.

[6] A. McWilliams and D. Siegel, "Corporate social responsibility: a theory of the firm perspective," Academy of Management Review, vol. 26, no. 1, pp. 117-127, 2001.
[7] H. T. Keh and C. W. Teo, "Retail customers as partial employees in service provision: a conceptual framework," International Journal of Retail \& Distribution Management, vol. 29, no. 8, pp. 370-378, 2001.

[8] M. Groth, "Customers as good soldiers: examining citizenship behaviors in internet service deliveries," Journal of Management, vol. 31, no. 1, pp. 7-27, 2005.

[9] M. Ahearne, C. B. Bhattacharya, and T. Gruen, "Antecedents and consequences of customer-company identification: expanding the role of relationship marketing," Journal of Applied Psychology, vol. 90, no. 3, pp. 574-585, 2005.

[10] B. Bartikowski and G. Walsh, "Investigating mediators between corporate reputation and customer citizenship behaviors," Journal of Business Research, vol. 64, no. 1, pp. 39-44, 2011.

[11] S. P. Huang and L. P. Chen, "An empirical study on the relationship among responsibility image, corporate identity and consumer response," Academia Bimestris, no. 4, pp. 158-163, 2013.

[12] H. L. Xiao and S. P. Li, "The impact of corporate social responsibility perception and consumer attribution on service recovery satisfaction of service enterprises: based on the mediating role of customer identity," Nankai Business Review, vol. 20, no. 3, pp. 124-134, 2017.

[13] L. Y. Jin, "An empirical study on corporate social responsibility evaluating scale system--consumers' viewpoint," China's Industrial Economy, no. 6, pp. 114-120, 2006.

[14] D. R. Lichtenstein, M. E. Drumwright, and B. M. Braig, "The effect of corporate social responsibility on customer donations to corporate-supported nonprofits," Journal of Marketing, vol. 68, no. 4, pp. 16-32, 2004.

[15] H. Q. Li and Z. G. Zhang, "An empirical study on the effects of corporate social responsibility on corporate reputation and customer loyalty," Nankai Business Review, vol. 13, no. 1, pp. 90-98, 2010.

[16] J. N. Sheth, B. I. Newman, and B. L. Gross, "Why we buy what we buy: a theory of consumption values," Journal of Business Research, vol. 22, no. 2, pp. 159-170, 1991.

[17] X. Y. Wang and J. B. Wu, "The unification of corporate social responsibility and profit based on consumers' social value," Journal of Chongqing University (Social Science Edition), vol. 21, no. 3, pp. 81-89, 2015.

[18] K. Butcher, B. Sparks, and F. O'Callaghan, "Evaluative and relational influences on service loyalty," International Journal of Service Industry Management, vol. 12, no. 4, pp. 310-327, 2001.

[19] T. W. Gruen, "The outcome set of relationship marketing in consumer markets," International Business Review, vol. 4, no. 4, pp. 447-469, 1995.

[20] M. Zhang, X. A. Xu, and X. R. Fu, "Impact of negative events on brand relationship in restaurant services: experimental study from the perspective of hierarchy of customers' interests," Tourism Tribune, vol. 29, no. 4, pp. 69-78, 2014.

[21] Y. Liu, "Reshaping Internet word of mouth marketing based on the constraints of business ethics," Enterprise Economy, vol. 30, no. 8, pp. 80-82, 2011.

[22] J. Guinot, "Changing the economic paradigm: towards a sustainable business model," International Journal of Sustainable Development and Planning, vol. 15, no. 5, pp. 603$610,2020$.

[23] J. Yan and L. R. Chen, "An appraisal model for marketingethics quality of online dealers," Chinese Journal of Management, vol. 5, no. 6, pp. 871-875, 2009. 
[24] L. Lyu, "Implementation and evaluation of corporate social performance and responsibility based on moral contract," Journal of Management, vol. 13, no. 11, pp. 1702-1709, 2016.

[25] Q. X. Wang, "Re analysis of the concepts of corporate responsibility and corporate social responsibility-Based on the new institutionalism theory of organizational sociology," Finance and Accounting Monthly, no. 13, pp. 152-157, 2019.

[26] Y. Lyu and H. Y. Wei, "A probe into measurement of customer extra-role behavior: scale construction and development," Journal of Beijing Business University (Social Science Edition), vol. 27, no. 2, pp. 49-54, 2012.

[27] Z. Y. Wang, "On the basis, performance and internalization of enterprise's moral responsibilities," Morality and Civilization, no. 3, pp. 36-41, 2005.

[28] J. C. Anderson and D. W. Gerbing, "Structural equation modeling in practice: a review and recommended two-step approach," Psychological Bulletin, vol. 103, no. 3, pp. 411-423, 1988. 